\title{
Environmental factors - spatial and temporal variation of chironomid communities in oceanic island streams (Azores archipelago)
}

\author{
Pedro Miguel Raposeiro ${ }^{1 *}$, Ana Cristina Costa $^{1}$ and Samantha Jane Hughes ${ }^{2}$ \\ ${ }^{1}$ Research Center in Biodiversity and Genetic Resources (CIBIO) - Açores, and Biology Department, University of Azores, \\ Rua Mãe de Deus 13A, 9501-855 Ponta Delgada, Açores, Portugal \\ 2 Centre for the Research and Technology of Agro-Environment and Biological Sciences, University of Trás-os-Montes e Alto Douro, \\ Apartado 1013, 5001-801 Vila Real, Portugal
}

Received 9 February 2011; Accepted 15 June 2011

\begin{abstract}
Freshwater systems on volcanic oceanic islands have very particular characteristics as a result of their geological origins, relatively small size, distances from source areas for colonizers, and distinct catchment morphology. These factors result in freshwater communities that are clearly distinct from continental systems. Chironomid spatial and temporal distribution was investigated in chironomid assemblages at 21 sites across the Azores Archipelago. Results using PERMANOVA, a permutational multivariate analysis of variance, indicated significant longitudinal differences in assemblages but none between islands or over time.

Links between hydromorphological and physicochemical variables and the community assemblage were assessed using DISTLM, a linear model for distance-based multivariate analysis. The percentage of variation explained by hydromorphological factors $(31 \%)$ was slightly higher than that explained by physicochemical $(28 \%)$ factors. Descriptors of land use (forest area, scrub area, natural area of catchment) and stream slope were found to be the best environmental predictors of chironomid assemblages in Azores. Physicochemical variables such as temperature, $\mathrm{pH}$, nitrite, iron and conductivity were the principal drivers of change in chironomid composition in stream locations. Headwater sites, characterized by lower temperature, acid to neutral $\mathrm{pH}$ values, low conductivity, nutrient and metal concentrations were dominated by Rheocricotopus atripes. Mid-section sites, located in agricultural areas were dominated by Thienemanniella clavicornis. Urbanized lower reaches were characterized by higher temperature, $\mathrm{pH}$, conductivity and nutrient levels and were dominated by Cricotopus sp. These results give essential information that allows us to predict the response of different chironomid species to hydromorphological and physicochemical gradients across the archipelago's streams contributing providing the basis for the development of tools for the implementation of the Water Frame Directive.
\end{abstract}

Key words: Chironomidae / environmental gradient / oceanic islands / spatial and temporal variation / insular streams / Azores

\section{Introduction}

Freshwater systems on volcanic oceanic islands differ from their continental counterparts due to their oceanic location (isolation), comparatively small size and geological youth. At a more local scale, catchment morphology and often a more extreme torrential seasonal flow regime also shape these systems. These biogeographical filters operate over a range of spatial scales, influencing colonizing organisms and events that shape the local freshwater

\footnotetext{
*Corresponding author: raposeiro@uac.pt
}

assemblage. Even the absence of given taxon provides evidence on mechanisms governing these processes (Bilton et al., 2001; Covich, 2006; Cowie and Brenden, 2006). Freshwater communities occurring on these islands tend to be depauperate but highly endemic (Borges and Brown, 1999; Walter, 2004; Hughes, 2006; Covich, 2009; Raposeiro and Costa, 2009). Oceanic island ecosystems tend to be simpler and offer great opportunities for the study of environmental factors determining the distribution of freshwater faunal elements such as the Chironomidae, the most abundant and diverse freshwater taxa in Azores archipelago (Raposeiro and Costa, 2009; 
Borges et al., 2010). Such studies provide a better understanding of the key environmental drivers of change in freshwater communities, essential for the development and implementation of regionally appropriate conservation measures and ecological monitoring programmes.

Many lotic ecological assessment protocols are based on benthic macroinvertebrates, one of the four biological elements specified in Water Frame Directive (WFD; European and The Council of the European, 2000) for assessing ecological status. However, many metrics, developed for continental streams and rivers, cannot be directly applied to insular systems, because of the distinct nature of their biotic assemblages [see Hughes (2005) for an overview of ecological monitoring on the Macaronesian islands]. For example, the commonly used EPT (Ephemeroptera, Plecoptera, Trichoptera) metric is inappropriate for Azores due to the absence of Plecoptera and the low diversity of both Ephemeroptera (one species reported) and Tricoptera (four species reported). Over twenty well-known metrics used to assess the suitability of macroinvertebrates in defining the ecological quality of Madeiran lotic systems based on perceived environmental impacts, were found to perform badly for the island of Madeira (Hughes, 2003). A similar situation was reported by Gonçalves et al. (2008) for the Azores.

A possible alternative approach is the study of the Chironomidae (Insecta, Diptera, Nematocera) as potential bioindicators of freshwater ecological status in Azorean streams, given their ubiquity, abundance and diversity. However, most macroinvertebrate based protocols only identify chironomids to family or sub-family or even omit them [e.g. Family Biotic Index - FBI (Hilsenhoff, 1988); Biological Monitoring Working Party - BMWP (Armitage et al., 1983)]. Chironomids are often excluded because of the difficult larval taxonomy that involves time consuming preparation of slides for subsequent identification and the large numbers of larvae that tend to occur in benthic samples. This is unfortunate, since chironomid diversity can match or even exceed that of other aquatic group insects combined (Heino and Paasivirta, 2008). Methods such as the Chironomid Pupal Exuviae Technique-CPET (Coffman, 1973; Wilson and Bright, 1973; Ruse and Wilson, 1995; Wilson and Ruse, 2005) largely overcome these difficulties because field and laboratorial protocols are well established and exuvial taxonomy is relatively easy, allowing identification to genus or even species. CPET is based upon the premise that the diversity and perceived tolerance of members of the aquatic chironomid larvae reflect local environmental conditions and that the winged adults ensure effective dispersal and colonisation of other aquatic habitats.

Situated in the North Atlantic, the Azores constitute the most remote archipelago of the Palaearctic sub region of Macaronesia, which also comprises the archipelagos of the Madeira, Canary and Cape Verde. The Azorean freshwater fauna is dominated by insects, in particular the Diptera (Gonçalves et al., 2008; Raposeiro and Costa, 2009; Raposeiro et al., 2009) and especially the Chironomidae, or non-biting midges (Borges, 2005;
Raposeiro and Costa, 2009). The Azorean chironomid fauna has been studied by several workers during the last century (e.g. Frey, 1945; Stora, 1945; Freeman, 1959). More recent records of Chironomidae were provided by Murray et al. (2004) and Raposeiro et al. (2009) who gave a total of 44 dipteran to the Azores and Raposeiro (2010) and Raposeiro et al. (in press) who updated the list.

Chironomid larvae inhabit almost every kind of aquatic habitat (Pinder, 1986; Ashe et al., 1987; Armitage et al., 1995a; Osborne et al., 2000). As a consequence they have been used as biological indicators in freshwater ecosystems (e.g. Rosenberg and Resh, 1993; Wilson and Ruse, 2005; Raunio et al., 2007b; Raunio et al., 2007a; Heino and Paasivirta, 2008). Further, studies relating environmental variables to the spatial and/or temporal patterns of chironomid distribution are reported from Australia (Hardwick et al., 1995; Dimitriadis and Cranston, 2007), Finland (Raunio et al., 2007b; Heino and Paasivirta, 2008), the United Kingdom (Ruse and Wilson, 1995; Ruse, 2000; Ruse and Davison, 2000), Spain (Calle-Martínez and Casas, 2006; Punti et al., 2009) and Japan (Inoue et al., 2005). The association between the environmental variables that determine chironomid community structure is complex, determined by physical, chemical and biological processes that vary both temporally and spatially in the lotic environment.

The principal aims of this study were to characterize chironomid communities of Azorean streams, using chironomid pupal exuviae to (i) determine if there are differences among chironomid assemblages between two islands of the Azores archipelago and (ii) identify environmental and chemical factors that determine chironomid assemblage structure both temporally and spatially.

These results will contribute to characterising chironomid distribution patterns along these particular lotic systems and provide information on factors determining the distribution of potential chironomid bioindicators across a quality gradient, ranging from reference to degraded conditions, paving the way to the development of regionally appropriate metric to describe ecological status, in accordance with the demands of the WFD (Hughes and Malmqvist, 2005; Hughes, 2006).

\section{Materials and Methods}

\section{Study area and sampling procedure}

The Azores is an oceanic archipelago, comprising 9 volcanic islands in three geographical groups (eastern, central and western groups), located between the coordinates 37 to $40^{\circ} \mathrm{N}, 25$ to $31^{\circ} \mathrm{W}$ (Fig. 1). The oceanic and temperate azorean climate is characterized by low thermal amplitude, high levels of precipitation, high air humidity, and persistent wind (Cruz, 2003), with mean annual temperatures of $14-18^{\circ} \mathrm{C}$ and mean annual precipitation of 740-2400 mm. Most annual precipitation $(65-70 \%)$ occurs between October and March (Bettencourt, 1979). 


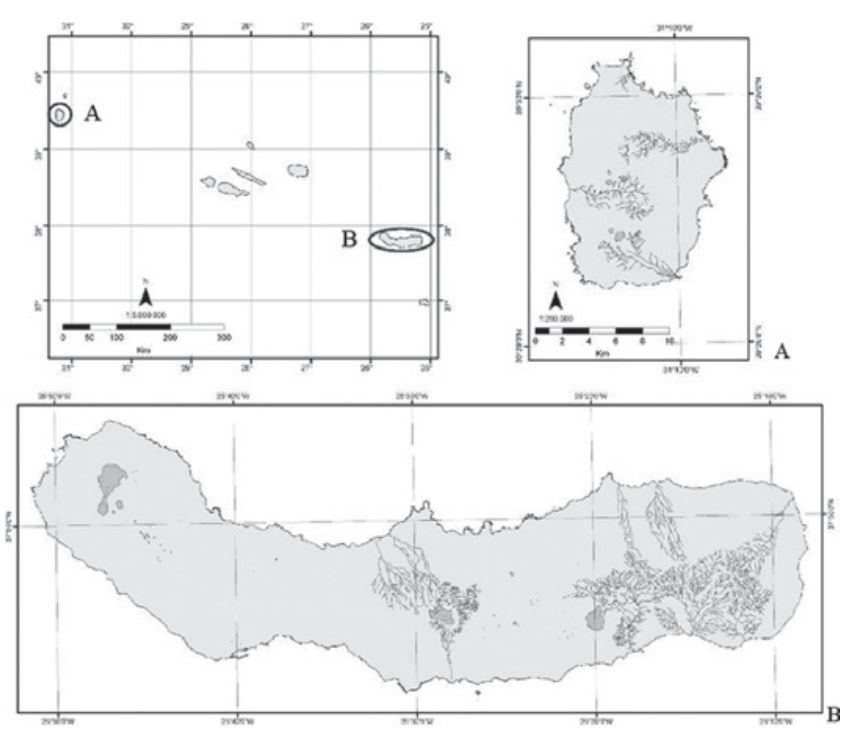

Fig. 1. The Azores archipelago: A) Flores island; B) São Miguel Island.

Azorean stream drainage networks are typically narrow and short with very steep, shallow channels often characterized by turbulent, torrential, and seasonal flow. Substrates are predominantly coarse, comprising bedrock, boulders, cobbles and sand. Background stream water chemistry is determined by (i) atmospheric input from oceanic-influenced precipitation, (ii) weathering of volcanic substrates and (iii) geothermal activity and spring water (Louvat and Allegre, 1998).

Forested areas (native and non-native) dominate the higher reaches of most catchments while agricultural and urban areas occupy the more accessible lower reaches. This study was conducted from early January to late November 2008, on the islands of São Miguel (eastern group, Fig. 1) and Flores (western group, Fig. 1). A total of 21 sites (seven in the headwater reaches, close to source; seven in mid-section reaches and seven in the lower reaches, close to the river mouth) along 10 permanent streams (eight in São Miguel and two in Flores) were selected and sampled to ensure adequate representation along both the altitudinal and anthropogenic gradient (Tab. 1). Although permanent streams, fed by lakes or spring waters, exist in Santa Maria, São Miguel, São Jorge, Faial and Flores islands (DROTRH and INAG, 2001), we selected São Miguel and Flores because they are the only islands where more than one permanent stream over $10 \mathrm{~km}^{2}$ in catchment area can be found.

Pupal exuviae were collected seasonally (winter, spring, summer and autumn) with a $250 \mu \mathrm{m}$ hand net over a 20 minute period along the stream margins, focusing on areas where flotsam (foam and floating material) accumulated behind obstacles such as exposed rocks and boulders (see Ferrington et al., 1991; Wilson and Ruse, 2005) in order to guarantee that a minimum of 200 exuviae were available for analysis (Wilson and Ruse, 2005). Collected material was placed in a $250 \mu \mathrm{m}$ sieve, washed and preserved in $96 \%$ ethanol. In the laboratory the material was sorted and identified to the lowest possible taxonomic level (species or species-group) using keys by Langton (1991) and Langton \& Visser (2003). Approximately 200 exuviae were subsampled randomly from each collection to provide an unbiased, representative sample (Ruse, 1993).

Physicochemical variables were measured at each site prior to biological sampling. Water temperature $\left({ }^{\circ} \mathrm{C}\right), \mathrm{pH}$ and dissolved oxygen (\%) were measured in situ with electronic field probes (DKK, model WQC-24). Water samples were collected and then transported to the laboratory in a cool box and analyzed using certified methods within 24 hours. Analysis determined concentrations of sulphate $\left(\mathrm{mg} \mathrm{SO}_{4} \mathrm{~L}^{-1}\right)$, phosphorus $\left(\mu \mathrm{P} \mathrm{L} \mathrm{L}^{-1}\right)$, Ammonium $\left(\mu \mathrm{g} \mathrm{NH}_{4} \mathrm{~L}^{-1}\right)$, Nitrite $\left(\mu \mathrm{g} \mathrm{NO}_{2} \mathrm{~L}^{-1}\right)$, Nitrate $\left(\mu \mathrm{g} \mathrm{NO} \mathrm{L}^{-1}\right)$, chloride $\left(\mathrm{mg} \mathrm{Cl} \mathrm{L}^{-1}\right)$, total iron $(\mathrm{mg} \mathrm{Fe}$ $\left.\mathrm{L}^{-1}\right)$, zinc (mg $\left.\mathrm{Zn} \mathrm{L} \mathrm{L}^{-1}\right)$, chromium $\left(\mu \mathrm{g} \mathrm{Cr} \mathrm{L}^{-1}\right)$, manganese $\left(\mu \mathrm{g} \mathrm{Mn} \mathrm{L}^{-1}\right)$, mercury $\left(\mu \mathrm{g} \mathrm{Hg} \mathrm{L}{ }^{-1}\right)$, arsenic $\left(\mu \mathrm{g} \mathrm{As} \mathrm{L}{ }^{-1}\right)$, cadmium $\left(\mu \mathrm{g} \mathrm{Cd} \mathrm{L}^{-1}\right)$, copper $\left(\mathrm{mg} \mathrm{Cu} \mathrm{L}^{-1}\right)$, sodium $\left(\mathrm{mg} \mathrm{Na} \mathrm{L}^{-1}\right)$ and hydrocarbons $(\mathrm{mg} / \mathrm{L})$. Conductivity $(\mu \mathrm{S} / \mathrm{cm})$, total suspended solids $\left(\mathrm{mg} \mathrm{L}^{-1}\right)$, biological oxygen demand $\left(\mathrm{mg} \mathrm{O}_{2} \mathrm{~L}^{-1}\right)$, chemical oxygen demand $\left(\mathrm{mg} \mathrm{O}_{2} \mathrm{~L}^{-1}\right)$, total and fecal coliforms (ufc/100 mL) were also determined in laboratory. Hydromorphological factors were obtained in ArcGis 9 (ESRI) using 1:25000 topographic maps (altitude, latitude, longitude, stream order, distance to mouth, distance to source and slope) for each site. Land use categories and areas (non-native forest, scrub, agriculture area, natural vegetation and urban areas) were obtained from Regional Planning Department of the Azores (Quaternaire-Portugal, 2008); a circular buffer area (200 m radius) was created around each sampling site. All described variables were obtained for each site, sample site and sampling season, with the exception of cartographic variables.

\section{Data analyses}

Several indices of species diversity (Magurran, 2004), such as Pielou's evenness, Fisher's $\alpha$ and Shannon-Wiener were calculated from the biological data. Non-redundant subsets of environmental and pressure parameters were obtained using the Pearson correlation coefficients to find and compare highly correlated parameters. If two environmental or pressure variables were highly correlated (threshold value of $r \geq 0.6$ ), then the variable with a highest overall mean correlation coefficient was excluded from subsequent analyses (Hering et al., 2006; Feld and Hering, 2007). A total of 7 environmental and 14 chemical variables were retained from an initial list of 13 environmental and 28 chemical variables (Tab. 2). Analyses were carried out using Primer 6.0 (Clarke and Gorley, 2006).

A Principal Components Analysis (PCA) was performed to identify abiotic gradients and patterns between streams. Permutational multivariate analysis of variance PERMANOVA (Anderson, 2001; McArdle and Anderson, 2001) was used to determine associations between the chemical variables and chironomid assemblages. PERMANOVA partitions the total sum of squares based 
Table 1. Location of sampling sites, respective sampling codes and UTM coordinates.

\begin{tabular}{|c|c|c|c|c|}
\hline Island & Stream & Location & Code & UTM \\
\hline \multirow{7}{*}{ Flores } & \multirow{4}{*}{ Grande } & Headwater sites & RGR0 & $25 \mathrm{~S} 654026 / 4366597$ \\
\hline & & Headwater sites & RGR1 & $25 \mathrm{~S} 652188 / 4368056$ \\
\hline & & Mid-section sites & RGR2 & 25S $651256 / 4366471$ \\
\hline & & Lower reaches sites & RGR3 & 25S $649839 / 4366831$ \\
\hline & \multirow{3}{*}{ Badanela } & Headwater sites & RBD0 & 25S $654106 / 4370554$ \\
\hline & & Headwater sites & RBD1 & $25 \mathrm{~S} 654126 / 4370547$ \\
\hline & & Lower reaches sites & RBD2 & $25 \mathrm{~S} 659820 / 4370524$ \\
\hline \multirow{14}{*}{ São Miguel } & \multirow{4}{*}{ Guilherme } & Headwater sites & RGU0 & 26S 658164/4184939 \\
\hline & & Mid-section sites & RGU1 & 26S 660669/4186486 \\
\hline & & Lower reaches sites & RGU2 & 26S 662931/4189980 \\
\hline & & Headwater sites & RFT0 & 26S 658356/4183665 \\
\hline & \multirow{2}{*}{ Faial da Terra } & Mid-section sites & RFT1 & 26S $659753 / 4182525$ \\
\hline & & Lower reaches sites & RFT2 & 26S 658977/4178911 \\
\hline & \multirow[b]{2}{*}{ Grande } & Headwater sites & RG1 & $26 \mathrm{~S} 635636 / 4182114$ \\
\hline & & Lower reaches sites & RG3 & $26 \mathrm{~S} 630243 / 4187075$ \\
\hline & Praia & Mid-section sites & RP0 & $26 \mathrm{~S} 634841 / 4178145$ \\
\hline & Teixeira & Mid-section sites & RTX2 & 26S $632100 / 4183838$ \\
\hline & Povoação & Lower reaches sites & RPV4 & $26 \mathrm{~S} 654812 / 4179468$ \\
\hline & Caldeirões & Mid-section sites & $\mathrm{RC} 2$ & 26S $651830 / 4190893$ \\
\hline & \multirow{2}{*}{ Quente } & Mid-section sites & RQ2 & 26S 649998/4182002 \\
\hline & & Lower reaches sites & RQ4 & 26S 654812/4179468 \\
\hline
\end{tabular}

on the full experimental design (given below), and calculates a distance based pseudo- $F$ statistic for each term in the model, based on the expectations of the mean squares. $P$-values are obtained using a permutation procedure for each term (Anderson et al., 2008), or via Monte Carlo random drawn from an asymptotic permutation distribution if too few permutations are available for a given test (Anderson and Robinson, 2003).

We tested for two spatial and one temporal distribution patterns using PERMANOVA: (i) between islands (fixed, two levels; Flores and São Miguel), (ii) over time (random, four levels: Winter, Spring, Summer and Autumn) and (iii) along the lotic longitudinal gradient (fixed, three levels: headwater sites; mid-section sites and lower reaches sites). Because chemical and environmental data have different measurement scales and similarity methods, we normalised data, according to Clarke and Gorley (2001). The relative abundance of the 21 species was $\log (\mathrm{x}+1)$ transformed to reduce differences in scale (Clarke and Green, 1988). For PERMANOVA, we used 9999 permutations of the data (an appropriate distribution for a pseudo- $F$ statistic under a true null hypothesis is obtained by using a permutation test. According to Anderson and Braak (2003) the programme permutes the units identified by the denominator term of the $F$-ratio).

SIMPER analysis was used to identify species' relative contribution to the groups resulting from PERMANOVA analyses. Bray-Curtis dissimilarities were calculated for all pairs of observations for the analyses below.

Links between the non-redundant set of hydromorphological and physicochemical variables (see Tab. 2) and the community assemblage were assessed using distancebased multivariate analysis for a linear model - DISTLM (Legendre and Anderson, 1999; McArdle and Anderson,
2001). DISTLM analyses and models the relationship between the multivariate data cloud, for one or more predictor variables (Anderson et al., 2008). DISTLM allows predictor variables to be fitted individually or together in user specified sets. The DistLM routine was based on the AIC model selection criterion (Burnham and Anderson, 2004) using a Step-wise selection procedure. The AIC model (Akaike, 1974; Akaike, 1973) was used to select the model that explained more variation, and therefore the 'best' model for that particular data set. Primer 6.0 and PERMANOVA + for PRIMER software were used (Clarke and Gorley, 2006; Anderson et al., 2008). For visual interpretation of the resulting model in multi-dimensional space, we used distance based redundancy analysis (dbRDA) to investigate the relationship between location, environmental and chemical variables (Anderson et al., 2008). Each vector begins at the centre of the circle (the origin) and ends in the coordinates ( $x$ and $y$ ). The length and direction of each vector indicates the strength and sign of the relationship between the given variable and the dbRDA axes. The overlaying vector illustrates the relationship between the eight variables identified by the DistLM procedure.

\section{Results}

\section{Physicochemical characterization}

PERMANOVA results (Tab. 3) showed significant temporal (Time $-\mathrm{F}_{3,57}=2.31, \quad P<0.002$ ) and spatial variation along longitudinal gradient (Location $\left.\mathrm{F}_{2,57}=5.49, P<0.007\right)$, but not between islands $(P>0.1)$. The PCA ordination also reflected this pattern (Fig. 2). 
Table 2. Hydromorphological and physicochemical (variables excluded from subsequent analyses in bold).

\begin{tabular}{|c|c|c|c|}
\hline$\overline{\text { Variable }}$ & Headwater sites & Mid-section sites & Lower reaches \\
\hline \multicolumn{4}{|l|}{ Hydromorphological } \\
\hline Production florest area (\%) & $31.84 \pm 43.41$ & $45.08 \pm 42.55$ & $\mathbf{0 . 0 0} \pm \mathbf{0 . 0 0}$ \\
\hline Scrub area $(\%)$ & $18.19 \pm 35.7$ & $18.20 \pm 36.13$ & $6.21 \pm 13.83$ \\
\hline Agriculture area $(\%)$ & $3.33 \pm 8.13$ & $17.15 \pm 36.14$ & $28.02 \pm 36.34$ \\
\hline Natural vegetation area $(\%)$ & $46.65 \pm 48.88$ & $19.56 \pm 35.18$ & $2.29 \pm 5.09$ \\
\hline Urban area $(\%)$ & $0.00 \pm 0.00$ & $0.00 \pm 0.00$ & $63.49 \pm 47.55$ \\
\hline Strahler Order & $2.74 \pm 0.71$ & $3.73 \pm 0.45$ & $5.00 \pm 0.60$ \\
\hline Altitude (m) & $605.48 \pm 104.07$ & $227.15 \pm 94.56$ & $13.78 \pm 7.38$ \\
\hline Distance to source (m) & $1777.03 \pm 818.87$ & $4914.74 \pm 2030.97$ & $9946.97 \pm 2212.69$ \\
\hline Distance to mouth (m) & $7329.49 \pm 1550.71$ & $4172.66 \pm 1951.03$ & $298.66 \pm 234.69$ \\
\hline Slope $(\%)$ & $10.06 \pm 8.53$ & $7.10 \pm 7.43$ & $5.28 \pm 3.69$ \\
\hline Latitude & $567290 \pm 214208$ & $649042 \pm 10544$ & $650514 \pm 10162$ \\
\hline Longitude & $4293730 \pm 92521$ & $4204560 \pm 59840$ & $4246894 \pm 91057$ \\
\hline \multicolumn{4}{|l|}{ Physicochemical } \\
\hline Temperature $\left({ }^{\circ} \mathrm{C}\right)$ & $14.63 \pm 3.14$ & $15.20 \pm 2.02$ & $17.74 \pm 2.88$ \\
\hline $\mathrm{pH}$ & $6.74 \pm 0.99$ & $7.45 \pm 0.45$ & $7.95 \pm 0.42$ \\
\hline Conductivity $(\mu \mathrm{S} / \mathrm{cm})$ & $76.71 \pm 32.07$ & $142.28 \pm 65.39$ & $225.31 \pm 103.35$ \\
\hline Total Suspended Solids $\left(\mathrm{mg} \mathrm{L}^{-1}\right)$ & $3.04 \pm 1.65$ & $11.88 \pm 30.13$ & $6.04 \pm 10.43$ \\
\hline Dissolved Oxygen $(\%)$ & $104.74 \pm 7.85$ & $104.96 \pm 7.06$ & $103.35 \pm 8.15$ \\
\hline Biological Oxygen Demand $\left(\mathrm{mg} \mathrm{O}_{2} \mathrm{~L}^{-1}\right)$ & $1.28 \pm 0.91$ & $1.25 \pm 1.00$ & $1.70 \pm 1.15$ \\
\hline Chemical Oxygen Demand $\left(\mathrm{mg} \mathrm{O}_{2} \mathrm{~L}^{-1}\right)$ & $11.00 \pm 9.43$ & $4.27 \pm 1.91$ & $5.09 \pm 4.07$ \\
\hline Ammonium $\left(\mu \mathrm{g} \mathrm{NH}_{4} \mathrm{~L}^{-1}\right)$ & $19.56 \pm 5.45$ & $27.88 \pm 27.93$ & $30.22 \pm 23.18$ \\
\hline Nitrite $\left(\mu \mathrm{g} \mathrm{NO}_{2} \mathrm{~L}^{-1}\right)$ & $4.17 \pm 5.51$ & $10.24 \pm 14.83$ & $11.39 \pm 10.76$ \\
\hline Nitrate $\left(\mathrm{mg} \mathrm{NO}_{3} \mathrm{~L}^{-1}\right)$ & $0.35 \pm 0.25$ & $1.36 \pm 1.63$ & $3.34 \pm 2.35$ \\
\hline Chloride (mg Cl L $\left.{ }^{-1}\right)$ & $12.37 \pm 2.65$ & $19.56 \pm 13.18$ & $21.78 \pm 5.05$ \\
\hline Sulfate $\left(\mathrm{mg} \mathrm{SO}_{4} \mathrm{~L}^{-1}\right)$ & $2.47 \pm 0.98$ & $9.82 \pm 27.93$ & $5.43 \pm 2.49$ \\
\hline Soluble Phosphate ( $\left.\mu \mathrm{g} \mathrm{P}_{2} \mathrm{O}_{5} \mathrm{~L}^{-1}\right)$ & $32.52 \pm 27.45$ & $125 \pm 65.47$ & $143.13 \pm 53.81$ \\
\hline Inorganic Phosphorus $\left(\mu \mathrm{g} \mathrm{P} \mathrm{L}^{-1}\right)$ & $25.56 \pm 18.77$ & $76.15 \pm 46.21$ & $74.52 \pm 44.56$ \\
\hline Total Phosphorus $\left(\mu \mathrm{g} \mathrm{P} \mathrm{L}^{-1}\right)$ & $30.07 \pm 21.09$ & $85.38 \pm 52.82$ & $94.13 \pm 63.03$ \\
\hline Chromium ( $\mu \mathrm{g} \mathrm{Cr} \mathrm{\textrm {L } ^ { - 1 } )}$ & $0.64 \pm 0.12$ & $0.60 \pm 0.02$ & $0.66 \pm 0.16$ \\
\hline Manganese $\left(\mu \mathrm{g} \mathrm{Mn} \mathrm{L}{ }^{-1}\right)$ & $56.67 \pm 52.33$ & $55.69 \pm 31.56$ & $91.74 \pm 104.87$ \\
\hline Iron $\left(\mathrm{mg} \mathrm{Fe} \mathrm{L}^{-1}\right)$ & $0.52 \pm 0.77$ & $0.21 \pm 0.22$ & $0.42 \pm 0.61$ \\
\hline Copper (mg Cu L $\left.{ }^{-1}\right)$ & $0.05 \pm 0.00$ & $0.05 \pm 0.00$ & $0.05 \pm 0.00$ \\
\hline $\operatorname{Zinc}\left(\mathrm{mg} \mathrm{Zn} \mathrm{L}^{-1}\right)$ & $0.02 \pm 0.00$ & $0.02 \pm 0.01$ & $0.02 \pm 0$ \\
\hline Cadmium ( $\left.\mu g \mathrm{Cd} \mathrm{L}^{-1}\right)$ & $0.60 \pm 0.00$ & $0.60 \pm 0.00$ & $0.60 \pm 0.00$ \\
\hline Mercury $\left(\mu \mathrm{g} \mathrm{Hg} \mathrm{L}^{-1}\right)$ & $0.30 \pm 0.00$ & $0.31 \pm 0.04$ & $0.31 \pm 0.06$ \\
\hline Lead $\left(\mu \mathrm{g} \mathrm{Pb} \mathrm{L} \mathrm{L}^{-1}\right)$ & $6.00 \pm 0.00$ & $6.00 \pm 0.00$ & $6.00 \pm 0.00$ \\
\hline Arsenic ( $\mu g$ As L $\left.L^{-1}\right)$ & $3.00 \pm 0.00$ & $3.46 \pm 1.42$ & $3.72 \pm 1.51$ \\
\hline Sodium $\left(\mathrm{mg} \mathrm{Na} \mathrm{L}^{-1}\right)$ & $10.41 \pm 6.26$ & $18.46 \pm 10.54$ & $32.46 \pm 22.42$ \\
\hline Hydrocarbons $\left(\mathrm{mg} \mathrm{L}^{-1}\right)$ & $0.02 \pm 0.00$ & $0.02 \pm 0.00$ & $0.02 \pm 0.00$ \\
\hline Total Coliforms (ufc/100 mL) & $177.04 \pm 323.36$ & $1034.62 \pm 2410.57$ & $4591.74 \pm 4562.55$ \\
\hline Fecal Coliforms (ufc/100 mL) & $63.7 \pm 100.73$ & $716.92 \pm 2090.45$ & $2283.91 \pm 3408.51$ \\
\hline
\end{tabular}

Table 3. Results of three-factor permutational multivariate analysis of variance (PERMANOVA) on normalized chemical data: Island (Is); Season (Se); Location (Lo); Time (Ti); and Residual (Res). Bold $\boldsymbol{F}$-values indicate significant $P$-values $(* P<0.05$, $* * P<0.01, * * * P<0.001)$.

\begin{tabular}{lccccc}
\hline Source of variation & $d f$ & SS & MS & Pseudo- $F$ & Unique perms \\
\hline Is & 1 & 25.522 & 25.522 & 1.9428 & 0.1266 \\
Se & 3 & 79.355 & 26.452 & 2.3102 & $\mathbf{0 . 0 0 1 5 * *}$ \\
Lo & 2 & 99.093 & 49.546 & 5.4868 & $\mathbf{0 . 0 0 6 9 * *}$ \\
IsxSe & 3 & 40.073 & 13.358 & 1.1666 & 0.2602 \\
IsxLo & 2 & 55.548 & 27.774 & 2.8566 & $\mathbf{0 . 0 0 9 4 * *}$ \\
SexLo & 6 & 52.053 & 8.6755 & 0.75769 & 0.8589 \\
IsxSexLo** & 5 & 48.246 & 9.6492 & 0.84274 & 0.7036 \\
Res & 57 & 652.64 & 11.45 & & 9939 \\
Total & 79 & 1106 & & & \\
\hline
\end{tabular}




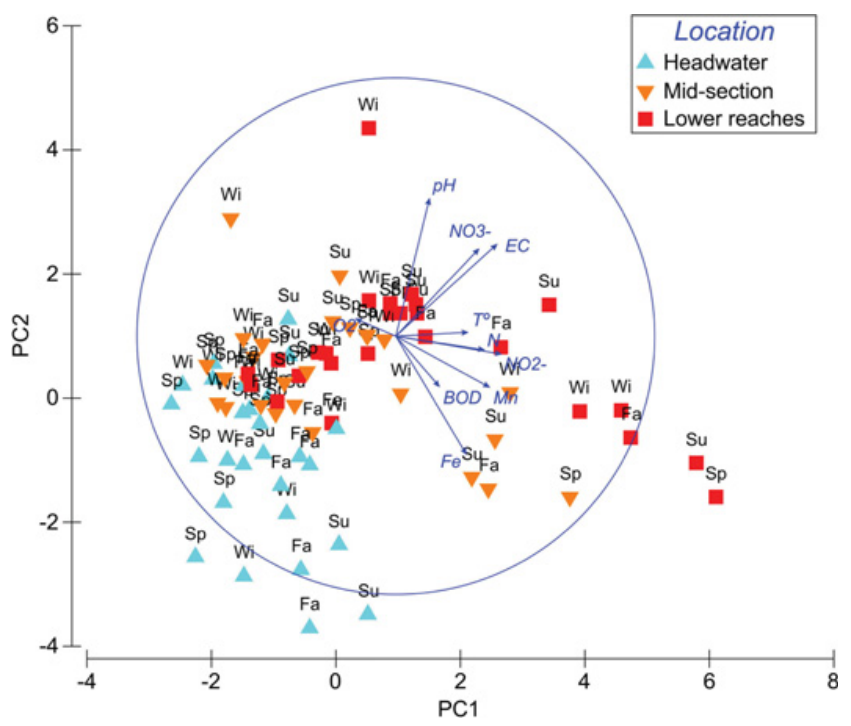

Fig. 2. Diagram of Principal Component Analysis of the chemical variables. Location are represented by: Headwater sites; Mid-section sites; and Lower reach sites. Time is presented by: Wi - Winter; Sp - Spring; Su - Summer and Fa - Fall. Solid arrows represent chemical variables: the length of the arrow indicates the importance of the variable while the direction of the arrowhead indicates the direction of increasing influence.

The first two PCA axes explained $39 \%$ of the variation and cumulatively $49 \%$ with the inclusion of the third axis. Temperature, conductivity, ammonium, nitrite, nitrate and phosphate compounds increased along the longitudinal gradient (Table 2) while dissolved oxygen, biological and chemical oxygen demand decreased. At most sites, dissolved oxygen values and $\mathrm{pH}$ were generally high during spring but decreased from summer and fall as a result of baseflow conditions.

\section{Azorean chironomids communities}

A total of 24 taxa were identified from 3 subfamilies and 5 tribes. The Orthocladiinae (15 taxa) showed the greatest richness, followed by Chironominae (6 taxa) and Tanypodinae (3 taxa). The Orthocladiinae was the dominant subfamily with a mean composition of $96 \%$. Orthocladiinae exuviae comprised between $27 \%$ and $100 \%$ of the total exuvias found.

Distinct spatial chironomid distribution patterns were apparent. Cricotopus sylvestris, Polypedilum nubeculosum and Pseudorthocladius curtistylus were exclusive to São Miguel Island, while Psectrocladius limbatellus, Pseudosmittia sp1 and Telmatopelopia nemorum were only collected from streams on Flores. T. nemorum and Zavrelimyia nubila occurred only at headwater sites, while Chironomus riparius, $C$. cingulatus, $C$. sylvestris, $C$. ornatus and $P$. nubeculosum were consistently absent from such sites (Appendix I). The most dominant species were Thienemanniella clavicornis and Orthocladius. fuscimanus,
Table 4. Average species number and species diversity indices in headwater sites, in mid-section sites and lower reaches sites.

\begin{tabular}{lccc}
\hline Deadwater & $\begin{array}{c}\text { Mid-section } \\
\text { sites }\end{array}$ & $\begin{array}{c}\text { Lower } \\
\text { reaches } \\
\text { sites }\end{array}$ \\
\hline Numbers of taxa & 5 & 7 & 7 \\
Pielou's evenness & 0.55 & 0.63 & 0.61 \\
Fisher's $\alpha$ & 0.45 & 0.56 & 0.57 \\
Shannon-Wiener & 0.87 & 1.16 & 1.09 \\
Diversity Index & & & \\
\hline
\end{tabular}

with mean composition per site of $39 \%$ and $17 \%$, respectively. These species were detected at least once for all sampling sites. Cardiocladius freyii was present at all sampling sites, with mean composition of $10 \%$ per site, with the exception of RFT1. Thienemanniella clavicornis, Orthocladius (Eudactylocladius) fuscimanus, C. freyii, Parametriocnemus stylatus and $R$. atripes occurred at more than $60 \%$ of the sampling sites. Species diversity indices varied considerably among sites (Tab. 4). The highest number of taxa was at RPV4 $(n=13)$ during the winter while the lowest number of taxa was at RGU2 and RFT0 in autumn, and RTX2 and RG1 in winter $(n=2)$.

\section{Spatial and temporal distribution patterns}

PERMANOVA results (Tab. 5) showed that chironomid assemblages differed significantly along the longitudinal gradient (Location $-\mathrm{F}_{2,56}=12.42, \quad P=0.004$ ), but not between islands $(P>0.05$ on all factors and interactions) or over time $(P>0.05$ on all factors and interactions). SIMPER results (Tab. 6) of longitudinal location indicated lower levels of dissimilarity between sites situated on mid-section reaches and headwater sites $(42 \%)$ and between headwater sites and mid-section sites (59\%), than that observed between headwater and lower reaches sites $(64 \%) . \quad R$. atripes, T. clavicornis, Cardiocladius freyii and $O$. fuscimanus were identified as the principal species contributing to the observed dissimilarity $(>50 \%)$ between the headwater sites and mid-section sites and between headwater sites and sites along the lower reaches. SIMPER results revealed longitudinal changes in percent abundance; in $R$. atripes $(2.6 \%$ - headwater sites; $1.4 \%$ - mid-section sites; $0.6 \%$-lower reaches sites), Cardiocladius freyii $(0.7 \%$ - headwater sites; $2.0 \%$ - midsection sites; $2.1 \%$ - lower reaches sites), O. fuscimanus $(1.8 \%$-headwater sites; $2.3 \%$ - mid-section sites; $2.6 \%$ - lower reaches sites) and P. stylatus $(0.3 \%$ - headwater sites; $1.5 \%$ - mid-section sites; $1.7 \%$ - lower reaches sites).

\section{Hydromorphological and physicochemical determinants of chironomids assemblages}

The most important hydromorphological variables explaining differences in stream location were altitude 
Table 5. Results of three-factor permutational multivariate analysis of variance (PERMANOVA) on relative abundance of chironomid: Island (Is); Time (Ti); Location (Lo) and Residual (Res). Bold $\boldsymbol{F}$-values indicate significant $P$-values $\left({ }^{*} P<0.05\right.$, $* * P<0.01, * * * P<0.001)$.

\begin{tabular}{|c|c|c|c|c|c|c|}
\hline Source of variation & $d f$ & SS & MS & Pseudo- $F$ & $P($ perm $)$ & Unique perms \\
\hline Is & 1 & 5758.4 & 5758.4 & 2.75 & 0.086 & 7827 \\
\hline $\mathrm{Ti}$ & 3 & 5818.3 & 1939.4 & 1.81 & 0.053 & 9920 \\
\hline Lo & 2 & 24483.0 & 12241.0 & 12.42 & $0.004 * *$ & 9941 \\
\hline Isx Ti & 3 & 5686.1 & 1895.4 & 1.77 & 0.060 & 9921 \\
\hline IsxLo & 2 & 2968.2 & 1484.1 & 1.71 & 0.170 & 9952 \\
\hline TixLo & 6 & 5834.3 & 972.4 & 0.91 & 0.577 & 9908 \\
\hline IsxTixLo & 5 & 4275.4 & 854.4 & 0.80 & 0.694 & 9920 \\
\hline Res & 56 & 59851.0 & 1068.8 & & & \\
\hline Total & 78 & 122690.0 & & & & \\
\hline
\end{tabular}

Table 6. Summary of SIMPER analysis results on the occurrence and relative abundance of chironomid taxa $(>10 \%)$.

\begin{tabular}{|c|c|c|c|c|c|}
\hline Species & $\begin{array}{c}\text { Average } \\
\text { abundance }\end{array}$ & $\begin{array}{c}\text { Average } \\
\text { abundance }\end{array}$ & $\begin{array}{c}\text { Average } \\
\text { dissimilarity }\end{array}$ & $\begin{array}{l}\% \text { Contribution } \\
\text { to dissimilarity }\end{array}$ & $\begin{array}{c}\text { Cumulative \% } \\
\text { contribution }\end{array}$ \\
\hline \multicolumn{6}{|l|}{ Average dissimilarity $=58.65 \%$} \\
\hline Rheocricotopus atripes & 2.62 & 1.38 & 8.52 & 14.52 & 14.52 \\
\hline Thienemanniella clavicornis & 2.43 & 3.50 & 7.77 & 13.25 & 27.78 \\
\hline Cardiocladius freyii & 0.66 & 2.03 & 7.18 & 12.24 & 40.02 \\
\hline Orthocladius fuscimanus & 1.78 & 2.27 & 6.81 & 11.60 & 51.62 \\
\hline \multicolumn{6}{|c|}{ Average dissimilarity $=63.76 \%$} \\
\hline & Headwater sites & Lower reaches sites & & & \\
\hline Rheocricotopus atripes & 2.62 & 0.55 & 10.12 & 15.80 & 15.80 \\
\hline Thienemanniella clavicornis & 2.43 & 3.19 & 8.28 & 12.93 & 28.74 \\
\hline Cardiocladius freyii & 0.66 & 2.06 & 7.60 & 11.87 & 40.61 \\
\hline Orthocladius fuscimanus & 1.78 & 2.61 & 7.41 & 11.58 & 52.18 \\
\hline Parametriocnemus stylatus & 0.27 & 1.77 & 7.16 & 11.19 & 63.37 \\
\hline \multicolumn{6}{|c|}{ Average dissimilarity $=41.58 \%$} \\
\hline & Mid-section sites & Lower reaches sites & & & \\
\hline Cricotopus sylvestris & 0.86 & 1.13 & 5.26 & 12.57 & 12.57 \\
\hline Orthocladius fuscimanus & 2.27 & 2.61 & 5.24 & 12.52 & 25.09 \\
\hline Cardiocladius freyii & 2.03 & 2.06 & 5.19 & 12.41 & 37.50 \\
\hline Rheocricotopus atripes & 1.38 & 0.55 & 5.14 & 12.28 & 49.78 \\
\hline Thienemanniella clavicornis & 3.50 & 3.19 & 5.14 & 12.28 & 62.06 \\
\hline
\end{tabular}

$(P<0.001)$, natural vegetation area $(P=0.002)$ and agricultural land use $(P=0.003)$, followed by urban area $(P=0.004)$, forest production $(P=0.005)$, slope $(P=0.013)$ and scrub vegetation areas $(P>0.05)$ identified in DistLM procedure (Tab. 7).

The Step-wise procedure selected altitude, production forest area, scrub area, natural vegetation area, slope and agriculture area as variables that determined chironomid composition in stream location $\left(\mathrm{AIC}=561.43 ; \mathrm{R}^{2}=0.34\right.$; number of variables $=6$ ).

The dbRDA ordination (Fig. 3) illustrated how sites were clearly separated by their location along the longitudinal gradient and the principal contributing environmental variables. The first two dbRDA axes explained $89 \%$ of the relationship between the chironomid assemblage and the measured hydromorphological variables, and $31 \%$ of the total variability in the community data.
Table 7. Summary of DistLM procedure for hydromorphological variables.

\begin{tabular}{lccc}
\hline Variable & SS (trace) & Pseudo- $F$ & $P$ \\
\hline Production forest area & 6113.4 & 4.01 & 0.005 \\
Scrub area & 3044.9 & 1.92 & 0.079 \\
Agriculture area & 7910.0 & 5.27 & 0.003 \\
Natural vegetation area & 8489.7 .9 & 5.68 & 0.002 \\
Urban area & 6994.7 & 4.62 & 0.004 \\
Altitude & 26163 & 20.69 & 0.001 \\
Slope & 4949.9 & 3.21 & 0.013 \\
\hline
\end{tabular}

The first dbRDA axis was strongly related to altitude while the second axis was related to land use (production forest, agriculture and natural vegetation area).

The most important chemical variables identified in DistLM routine were water temperature $(P=0.001)$, 
Table 8. Summary of DistLM procedure for physicochemical variables.

\begin{tabular}{lccc}
\hline Variable & SS (trace) & Pseudo- $F$ & $P$ \\
\hline Water temperature pH & 12389 & 8.6487 & 0.001 \\
Conductivity & 16962 & 12.353 & 0.001 \\
Total suspended solids & 14317 & 10.172 & 0.001 \\
Dissolved oxygen & 607.98 & 0.38347 & 0.839 \\
Biological Oxygen Demand & 758.6 & 0.47906 & 0.767 \\
Ammonium & 1138.7 & 0.72134 & 0.605 \\
Nitrite & 2617.3 & 1.6784 & 0.127 \\
Nitrate & 7085.9 & 4.7197 & 0.006 \\
Manganese & 9959.5 & 6.8028 & 0.001 \\
Iron & 3211.6 & 2.0698 & 0.080 \\
Zinc & 5236.3 & 3.4328 & 0.010 \\
Mercury & 1225.6 & 0.77694 & 0.532 \\
Hydrocarbons & 910.34 & 0.57559 & 0.668 \\
\hline
\end{tabular}

pH $(P=0.001)$, conductivity $(P=0.001)$ and nitrate $(P=0.001)$ as the principal determinants of chironomid composition along the longitudinal gradient. Nitrite $(P=0.006)$ and total iron $(P=0.01)$ were also important parameters (Tab. 8). The Step-wise procedure selected temperature, $\mathrm{pH}$, nitrite, iron and conductivity as the strongest parameters determining chironomid composition in relation to stream location $(\mathrm{AIC}=562.16$; $\mathrm{R}^{2}=0.32 ; \mathrm{n}^{\circ}$ of variables $\left.=5\right)($ Tab. 8$)$.

The dbRDA for chemical variables (Fig. 4) also showed a clear longitudinal separation of stream sampling sites and the principal contributing chemical variables ( $\mathrm{pH}$, nitrite, iron and temperature). The first two dbRDA axes captured $87 \%$ of the variability in the fitted model, and $28 \%$ of the total variation in the location. The vector overlays showed the relationship between the five variables found by the DistLM procedure. The first dbRDA axis was negative in relation to $\mathrm{pH}$ and nitrite and positive in relation to iron. The second axis showed a strong positive relationship with temperature.

\section{Discussion}

The number of chironomid taxa recorded in Azorean streams was low (24) compared to typologically similar continental rivers (e.g. mountain rivers) and other macaronesian streams. For example, 71 taxa were recorded at Aude River (Gendron and Laville, 1995) in France, 107 taxa at Pang River (Ruse and Wilson, 1995), in United Kingdom, 54 taxa in Tenerife Island (Armitage et al., 1995b) and 46 taxa on the island of Madeira (Hughes, 2003). Similar to findings from Madeira (Hughes, 2003) and Tenerife (Armitage et al., 1994), the Orthocladiinae and Chironominae were the most frequently observed subfamilies in Azorean streams (Murray et al., 2004; Raposeiro et al., 2009). Similar to Tenerife (Armitage et al., 1994), Thienemaniella clavicornis is the most dominant species in Azorean streams, but appears to be far rarer on Madeira (Hughes, 2003).

Bilton et al. (2001) described active and passive dispersal mechanisms for success in the colonization of

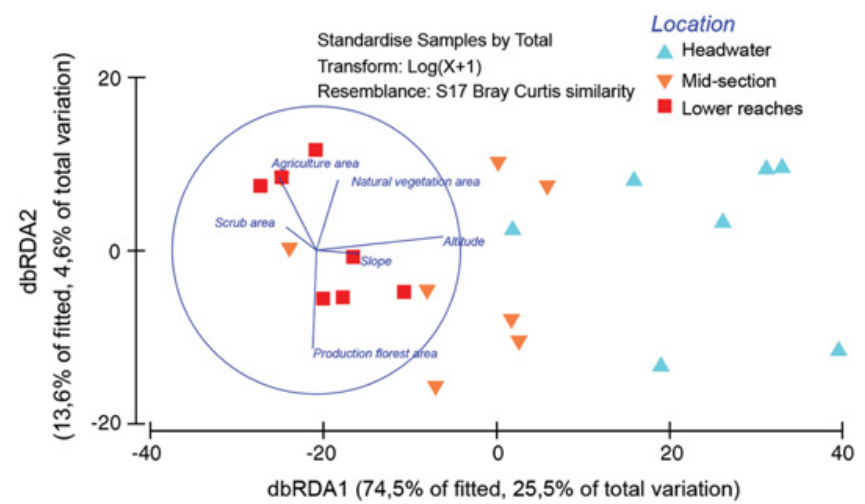

Fig. 3. Distance-based RDA ordination of first and second fitted axes relating the environmental variables to chironomid composition on different stream location. Vectors projections are given for the environmental variables selected by the DistLM routine. Length and direction of the vectors represent the strength and direction of the relationship.

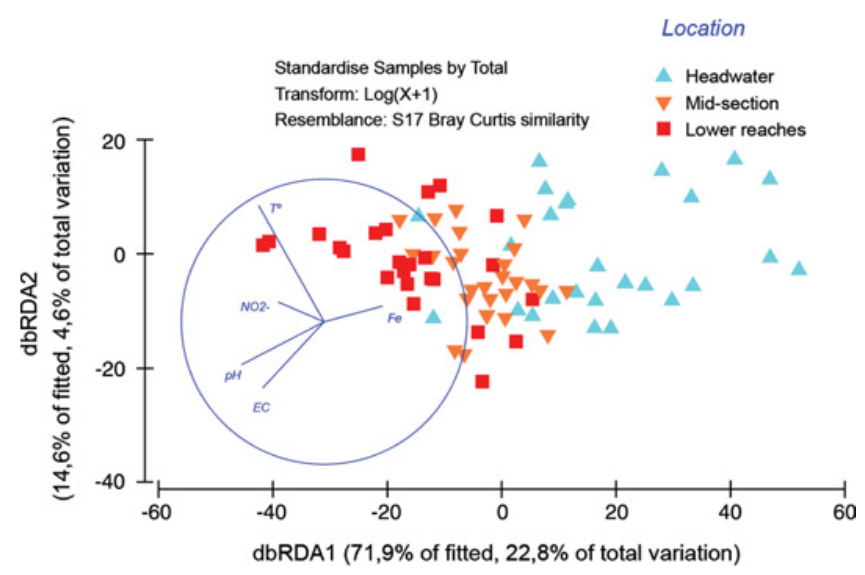

Fig. 4. Distance-based RDA ordination of first and second fitted axes relating the chemical variables to chironomid composition on different stream location. Vectors projections are given for the chemical variables selected by the DistLM routine. Length and direction of the vectors represent the strength and direction of the relationship.

freshwater systems. Actively flying chironomids adults can disperse over large areas (Massaferro and Brooks, 2002), allowing the colonization of numerous freshwater ecosystems on the same island or even in neighbouring islands, which partly explains the high levels of similarity between the two islands in this study. In a setting such as the Azorean archipelago, active dispersal methods are important for the "stepping stone" type freshwater habitat colonization between islands (Whittaker and FernandezPalacios, 2007).

\section{Spatial variability: hydromorphological and physicochemical factors}

The present study provides information about the physicochemical and hydromorphological variables 
determining chironomid assemblage distribution patterns in Azorean streams. An understanding of both local and large-scale environmental factors is vital in order to assess the importance of their role in structuring chironomid communities (Punti et al., 2007; Calle-Martínez and Casas, 2006; Punti et al., 2009). Differences in chironomid assemblage structure between islands were not apparent $(P=0.068)$ but were significantly different along the lotic longitudinal gradient $(P=0.004)$.

Physicochemical and hydromorphological variables explained $58.5 \%$ of the variance in chironomid assemblage composition. These values are similar to those determined in several previous studies on benthic diatoms (Soininen et al., 2004), macroinvertebrates (Mykrä et al., 2007; Heino and Paasivìrta, 2008) and fish (Magalhaes et al., 2002). The percentage of variance in chironomids assemblages explained only by hydromorphological variables in our study was considerable $(30.8 \%)$ and similar to the percentage of variation explained by physicochemical variables $(27.7 \%)$. The relatively high percentage of unexplained variation $(41.5 \%)$ in our study is typical of noisy data sets with many 0 values (Borcard et al., 1992), and could be result of abiotic and biotic factors not considered in this study, such as species' interactions (Kohler, 1992), food availability (Peeters et al., 2004), reproduction, competition and predation (MacNeil et al., 1999).

The similarity of the faunal assemblages between islands appears to be related to the physical and chemical similarities of the islands' streams coupled with the chironomid dispersal abilities. PERMANOVA results did not detect significant spatial differences in physicochemical composition between islands $(P>0.1)$, but did detect significant differences along the lotic longitudinal gradient $(P<0.007)$. This emphasizes the importance of local, lower scale physicochemical and hydromorphological in determining the longitudinal distribution patterns of the chironomid community following colonization.

Habitat complexity also influences the composition of the freshwater assemblages (Heino, 2000; Tolonen et al., 2001; White and Irvine, 2003). Coffman (1995, 1989) proposed ecological heterogeneity as one of the main factors influencing chironomid species richness. To date, no detailed data on habitat complexity in Azorean streams is available. However, field observations indicate that key drivers such as substrate and flow are very similar between islands. Several authors (Malmqvist, 2002; Hughes and Malmqvist, 2005) have reported low spatial heterogeneity and low habitat diversity in Macaronesian systems (almost all streams are narrow, steep, with coarse substrate and typical step-pool flow patterns). The similar chemical composition and low spatial heterogeneity appears to be reflected in the expected high similarity of chironomids assemblages found in both islands.

$T$. clavicornis, $O$. fuscimanus and $R$. atripes dominated sampling sites on both São Miguel and Flores islands. These species are known to posses a high dispersion ability and are well represented in the Palaearctic (Saether and Spies, 2009) and Macaronesian regions (Oromí and Báez, 2001; Hughes, 2008).
The islands under study have suffered dramatic changes in land use following human colonization in the fifteenth century when the native vegetation at low and middle altitudes was cleared or became gradually extinct. In the 20th century, an increase in land dedicated to pasture has further depleted small fragments of native vegetation at mid range altitudes (Silva and Smith, 2004). Nowadays, indigenous forested areas are limited to mid to high altitude (approximately $>600 \mathrm{~m}$ ). However midrange reaches are considerably altered by human intervention including agriculture, canalization, flow diversion and organic discharge and almost all lower reaches are affected by urbanization. This study has clearly shown that changes in land use exerted a significant effect on longitudinal changes in chironomid assemblage composition along the stream represented by the secondary axes of the dbRDA.

Many authors highlight agriculture as a major cause of degradation in stream habitats (Allan and Flecker, 1993; Allan, 2004), and that the biological impacts of physical alterations from this activity can last for decades (Harding et al., 1998). This type of impact contrasts with the impacts of urbanization which are mainly related to direct effects of point source pollution, hydromorphological and biological impacts (Brasher, 2003; Feld and Hering, 2007; Mykrä et al., 2007; Munné and Prat, 2009; Weijters et al., 2009). The physicochemical gradient of temperature, $\mathrm{pH}$ and conductivity in this study illustrates the indirect, combined effect of multiple mechanisms operating over several spatial scales describing natural biotic and abiotic gradients, changes in land use an organic enrichment (Hughes et al., 2009). Most of the retained variables e.g. increase of nitrogen and phosphate compounds, increase of coliforms also described consequences of changes of the land use along the longitudinal gradient (see Tab. 2).

The dbRDA ordinations revealed scale dependent environmental and chemical variables with potentially high levels of covariance. In fact, the history of colonization of the archipelago (the Azores have suffered dramatic changes in land due to colonization, remaining indigenous forested mostly in high altitude) combined with the natural spatial and temporal patterns of insular streams could obscure the ready distinction of these sources of variation. Similar situations were reported by authors for the Mediterranean systems (Díaz et al., 2008; Hughes et al., 2009). The increase in nutrient levels along the longitudinal gradient observed in the Azorean streams is consistent other studies identifying chironomid composition changes along the river continuum, in association with altitude and stream order (Lindegaard and Brodersen, 1995; Heino, 2005; Inoue et al., 2005; Heino and Paasivirta, 2008).

Chironomid species richness, evenness and diversity tended to be lower at headwater sites (2nd-3rd order), increasing to maximum values at sites midway along the longitudinal gradient (3rd-4th order), before decreasing again at sites further downstream (5th-6th order). These findings partly agree with Coffman (1989), who found maximum richness of lotic chironomids in 3rd order streams (e.g. RC2; RQ2) as a result of higher ecological 
heterogeneity. The patterns revealed by the three diversity indices are also consistent with the Connell's intermediate disturbance hypothesis, (Connell, 1978), which describes maximal species richness at intermediate levels of disturbance (Tab. 7). Vannote et al. (1980) and Giller and Malmqvist (1998) attributed the increase in diversity from headwaters to mid section of freshwater courses to increasing temperature, improved light conditions and broader stream channels. Moore and Palmer (2005) also reported higher invertebrate biodiversity in agricultural streams which then progressively declined along a land use gradient towards urbanization. Three groups of chironomids (headwaters, mid-section and low reaches) were discernible in relation to the influence of environmental variables [identified in PERMANOVA test $\left(\mathrm{F}_{2,54}=3.21\right.$, $P=0.004)]$. The dbRDA results clearly indicated a strong environmental framework structuring the characteristics of both the sites and taxa.

The right-hand side of the dbRDA ordination was occupied mainly by headwater sites in semi-pristine conditions, located in scrub or natural vegetation. These sites were characterized by low temperatures, circumneutral $\mathrm{pH}$, low conductivity, nutrients and metals. $R$. atripes was the most abundant species at headwater sites; $Z$. nubila and Paramerina cingulata were restricted to these habitats, indicated by SIMPER analysis results. According to Vallenduuk and Moller Pillot (2007), these latter two Tanypod species tend to occur in the water surface layer of soil or plants, or in pools. These features indicate more stable habitats, when compared with bedrock habitats, with low levels of disturbance (Townsend and Hildrew, 1994). Milner and Petts (1994) proposed stream channel stability as a major environmental factor determining stream community structure. The left-hand of the dbRDA ordinations were occupied by samples from stream sites located in areas subject to high levels of human intervention. These sites were lower lying, located close to urbanized areas and displayed higher temperature, $\mathrm{pH}$, conductivity and nutrient levels. C. sylvestris and $P$. stylatus typically occurred at lower reaches locations. Several studies have reported that Cricotopus is abundant at nutrient enriched sites (e.g. Davies and Hawkes, 1981; Wilson, 1992; Calle-Martínez and Casas, 2006; Maasri et al., 2008). Increased nutrient levels at mid-section sites adjacent to agriculture and areas dedicated to grazing of livestock appeared to augment chironomid abundance. T. clavicornis and Synorthocladius semivirens were more abundant at such sites while Pseudorthocladius curtistylatus and Polypedilum nubeculosum were exclusive to these sites. T. clavicornis, Cardiocladius freyii and O. fuscimanus were the most abundant species and are tolerant to a wide range of conditions.

\section{Temporal variability}

Despite the distinct seasonal climatic patterns, PERMANOVA results did not detect significant temporal patterns $(P>0.05)$ in chironomid composition (Tab. 5) but did detect significant differences in chemical composition (Time $-\mathrm{F}_{3,56}=23814, \quad P=0.002$ ). These findings indicate seasonal persistence in community patterns. SIMPER analysis results showed that $T$. clavicornis consistently contributed over $30 \%$ to group similarity, followed by $O$. fuscimanus (contribution $>18 \%$ ) and Cardiocladius freyii (contribution $>8 \%$ ). These species predominated in the sampled streams throughout the entire sampling period.

Persistence and stability of the 3 most abundant taxa were consistently high across the entire community, suggesting a temporally persistent pool of common taxa in Azorean streams, similar to other studies in continental streams (Townsend et al., 1987; Winterbourn, 1997). However, further research is required to understand the strategies employed by these core chironomid taxa. Seasonal persistence of the chironomid communities is consistent with the results of previous studies of macroinvertebrates communities in Mediterranean streams (Mellado, 2005; Bêche et al., 2006). Observed persistence in Azorean chironomid communities in this study could be the result of naturally high disturbance levels which are typical of oceanic islands (Hughes, 2005; Covich, 2006; Covich, 2009) and act as selective filters favouring species adapted to such conditions.

Chironomid emergence patterns vary both temporally and spatially across streams and voltinism varies both interspatially and intraspatially (Wrubleski and Rosenberg, 1990). Most chironomid lotic species are multivoltine (three or more generations per year) with peaks in emergence occurring between spring and autumn (Tokeshi et al., 1995). The presence of several species across the four sampling seasons could be explained by the continuous emergence of species from overlapping generations or cohorts. Small sized species such T. are multivoltine and often observed to posses closely overlapping generations (Tokeshi et al., 1995). Multivoltine species are better adapted to exploit situations of environmental change, especially when rapid fluctuations occur (Delettre, 1995), such as rapid runoff and highly torrential flow regimes which are common after rainfall on the Azores.

\section{Final remarks}

Relatively reduced habitat diversity, low spatial heterogeneity, distance from sources of colonization and the geological youth of the Azores archipelago, limit the pool of invertebrates able to colonize and inhabit Azorean streams, a phenomenon common to other Macaronesian islands (Hughes and Malmqvist, 2005; Hughes, 2005; Hughes, 2006).

Local changes in the physical environment due to changes in land use (agriculture and forestry, urbanization) alter local habitat quality, influencing community composition and biodiversity. Our results confirm that chironomids constitute a promising candidate group for ecological assessment in Azorean lotic systems, but larger 
data sets are required to better analyze intraannual and interannual variability and the effect of habitat scale variables. A better understanding of the ecological requirements of chironomid communities in Azorean streams and their biology is essential for developing water-quality monitoring protocols suitable for insular streams. More detailed of life cycles and emergence patterns over several seasons will provide more information on chironomid phenology. All of these findings would contribute to testing and possibly adapting the Chironomid Pupal Exuviae Technique (CPET) to Azorean surface waters.

The information from this study will help support current and future research of Azorean stream ecosystems and future freshwater management issues such as conservation planning, management measures, implementing biomonitoring programmes, and predicting of how human alterations will affect lotic ecosystems, allowing the development and implementation of sustainable and effective natural resource management across the archipelago.

Acknowledgements. Part of this study was financed by Fundação para a Ciência e Tecnologia (FCT - SFRH/BD/28798/2006). We thank João Ramos, Andreia Cunha e Mafalda Cruz for helping in the field and laboratory work. We also thank to Gustavo Martins helpful comments and suggestions that improved the scope and content of the manuscript. We thank all the CIGPT members for providing environmental data, and Inova for the chemical data. We also thank 2 anonymous referees for comments that improved earlier versions of this paper.

\section{References}

Akaike H., 1973. Information theory and an extension of the maximum likelihood principle. In: Petrov B.N. and Csake F. (eds.), Second International Symposium on Information Theory, Akademiai Kiado, Budapest, 267-281.

Akaike H., 1974. A new look at the statistical model identification. IEEE Transactions on Automatic Control, AC-19, 716-723.

Allan J.D., 2004. Landscapes and riverscapes: The Influence of Land Use on Stream Ecosystems. Annu. Rev. Ecol. Syst., 35, 257-284.

Allan J.D. and Flecker A.S., 1993. Biodiversity conservation in running waters. Identifying the major factors that threaten destruction of riverine species and ecosystems. BioScience, $43,32-43$.

Anderson M.J., 2001. A new method for non-parametric multivariate analysis of variance. Austral Ecol., 35, 32-46.

Anderson M.J. and Braak C.J.F., 2003. Permutations test for multi-factorial analysis of variance. Journal of Statistical Computation and Simulation, 73, 85-113.

Anderson M.J., Gorley R.N. and Clarke K.R., 2008. PERMANOVA + for PRIMER: Guide to Software and Statistical Methods, PRIMER-E, Plymouth, UK, 214.

Anderson M.J. and Robinson J., 2003. Generalized discriminant analysis based on distances. Aust. N. Z. J. Stat., 45, 301-318.
Armitage P., Cranston P.S.V. and Pinder L.C.V., 1995a. The Chironomidae - The biology and ecology of non-biting midges, Chapman \& Hall, London, xii +572.

Armitage P.D., Blackburn J.H., Malmqvist B. and Nilsson A.N., 1994. Chironomidae in freshwater habitats in Tenerife, Canary Islands. In: Cranston P.S. (ed.), Chiromonids from genes to ecosystems, CSIRO publications, Melbourne, 379-388.

Armitage P.D., Blackburn J.H., Nilsson A.N. and Malmqvist B., 1995b. Chironomidae in freshwater habitats in Tenerife, Canary Islands. In: Peter C. (ed.), Chironomids. From Genes to Ecosystems, CSIRO, Australia, 379-388.

Armitage P.D., Moss D., Wright J.F. and Furse M.T., 1983. The performance of a new biological water quality score system based on macroinvertebrates over a wide range of unpolluted running-water sites. Water Res., 17, 333-347.

Ashe P., Murray D.A. and Reiss F., 1987. The zoogeographical distribution on Chironomidae. Ann. Limnol., 23, 27-60.

Bêche L.A., Macelravy E.P. and Resh V.H., 2006. Long-term seasonal variation in the biological traits of benthicmacroinvertebrates in two Mediterranean climate streams in California, U.S.A. Freshwat. Biol., 51, 56-75.

Bettencourt M.L., 1979. O clima dos Açores como recurso natural na aplicação especialmente em agricultura e indústria do turismo, Instituto Nacional de Meteorologia e Geofísica, Lisboa, 63.

Bilton D.T., Freeland J.R. and Okamura B., 2001. Dispersal in freshwater invertebrates. Annu. Rev. Ecol. Syst., 32, 159-181.

Borcard D., Legendre P. and Drapeau P., 1992. Partialling out the spatial component of ecological variation. Ecology, 73, 1043-1055.

Borges P.a.V., 2005. Capitulo 2 Descrição da Biodiversidade Terrestre dos Açores. In: Borges P.a.V., Cunha R., Gabriel R., Martins A.F., Silva L., Vieira V., Dinis F., Lourenço P., Pinto N., Cunha R., Gabriel R., Martins A.F., Silva L. and Vieira V. (eds.), Listagem da Fauna e Flora (Mollusca e Arthropoda) (Bryophyta, Pteridophyta e Spermamatophyta) Terrestre dos Açores., Projecto Interreg III B (2000-2006) Atlântico, Direcção Regional do Ambiente, Governo Regional dos Açores, Rua Cônsul Dabney, Colónia Alemã, 9900-014, Horta, Faial, 23-68.

Borges P.a.V. and Brown V.K., 1999. Effect of island geological age on the arthropod species richness of Azorean pastures. Biol. J. Linn. Soc., 66, 373-410.

Borges P.a.V., Costa A., Cunha R., Gabriel R., Gonçalves V., Frias Martins A.M., Melo I., Parente M., Raposeiro P., Rodrigues P., R.S.S., Silva L. and Vieira V., 2010. Description of the terrestrial and marine Azorean biodiversity. In: Borges P.a.V., Costa A., Cunha R., Gabriel R., Gonçalves V., Frias Martins A.M., Melo I., Parente M., Raposeiro P., Rodrigues P., R.S.S., Silva L. and Vieira V. (eds.), A list of the terrestrial and marine biota from the Azores, Principia, Cascais, 9-33.

Brasher A.M.D., 2003. Impacts of Human Disturbances on Biotic Communities in Hawaiian Streams. BioScience, 53, 1052-1060.

Burnham K.P. and Anderson D.R., 2004. Multimodel inference: understanding AIC and BIC in model selection. Soc. Method. Res., 33, 261-304.

Calle-Martínez D. and Casas J.J., 2006. Chironomid species, stream classification, and water-quality assessment: the case 
of 2 Iberian Mediterranean mountain regions. J. N. Am. Benthol. Soc., 25, 465-476.

Clarke K.R. and Gorley R.N., 2001, PRIMER v5: User manual/ tutorial. Plymouth, UKPRIMER-E, $91 \mathrm{pp}$.

Clarke K.R. and Gorley R.N., 2006, PRIMER v6: User manual/ tutorial. PRIMER-E, Plymouth, UK, $115 \mathrm{pp}$.

Clarke K.R. and Green R.H., 1988. Statistical design and analysis for a 'biological effects' study. Mar Ecol Prog Ser, 46, 213-226.

Coffman W.P., 1973. Energy flow in a woodland stream ecosystem. The taxonomic composition and phenology of the Chironomidae as determined by the collection of pupal exuviae. Archiv für Hydrobiolie, 71, 281-322.

Coffman W.P., 1989. Factors that determine the species richness of lotic communities of Chironomidae. Acta Biologica Debrecina, Suppl. Oecologica Hungarica, 3, 95-100.

Coffman W.P., 1995. 18 Conclusions. In: Armitage P.D., Cranston P.S. and Pinder L.C.V. (eds.), The Chironomidae: Biology and ecology of non-biting midges., Chapman \& Hall, London, 436-572.

Connell J.H., 1978. Diversity in Tropical Rain Forests and Coral Reefs. Science, 199, 1302-1310.

Covich A.P., 2006. Dispersal-limited biodiversity of tropical insular streams. Polish J. Ecol., 54, 523-547.

Covich A.P., 2009. Freshwater ecology. In: Gillespie R.G. and Clague D.A. (eds.), Encyclopedia of islands, University of California Press, Berkeley, 343-347.

Cowie R.H. and Brenden S.H., 2006. Dispersal is fundamental to biogeography and the evolution of biodiversity on oceanic islands. J. Biogeogr., 33, 193-198.

Cruz J.V., 2003. Groundwater and volcanoes: examples from the Azores archipelago. Environ. Geol., 44, 343-355.

Davies L.J. and Hawkes H.A., 1981. Some effects of organic pollution on the distribution and seasonal incidence of Chironomidae in riffles in the River Cole. Freshwat. Biol., 11, 549-559.

Delettre Y.R., 1995. Heathland fires temporarily increase species diversity: an example in terrestrial Chironomidae (Diptera). Landscape Urban Plann., 31, 259-268.

Díaz A.M., Alonso M.L.S. and Gutiérrez M.R.V.-A., 2008. Biological traits of stream macroinvertebrates from a semiarid catchment: patterns along complex environmental gradients. Freshwat. Biol., 53, 1-21.

Dimitriadis S. and Cranston P.S., 2007. From the mountains to the sea: assemblage structure and dynamics in Chironomidae (Insecta: Diptera) in the Clyde River estuarine gradient, New South Wales, south-eastern Australia. Aust. J. Entomol., 46, 188-197.

DROTRH and INAG, 2001. Plano Regional da Água. Relatório Técnico. Versão para Consulta Pública, Direcção Regional do Ordenamento do Território e dos Recursos Hídricos e Instituto da Água, Ponta Delgada, 414.

European P. and The Council of the European U., 2000. Directive 2000/60/EC of the European Parliament and of the Council establishing a framework for the Community action in the field of water policy. OJEC, 327, 1-72.

Feld C.K. and Hering D., 2007. Community structure or function: effects of environmental stress on benthic macroinvertebrates at different spatial scales. Freshwat. Biol., 52, $1380-1399$.

Ferrington L.C., Blackwood M.A., Wright C.A., Crisp N.H., Kavanaugh J.L. and Schmidt F.J., 1991. A Protocol for
Using Surface-Floating Pupal Exuviae of Chironomidae for Rapid Bioassessment of Changing Water Quality. In: Publication I. (ed.), Sediment and Stream Water Quality in a Changing Environment: Trends and Explanations, Vienna, 181-190.

Freeman P., 1959. Chironomidae (Diptera, Nematocera) from Azores and Madeira. Bol. Mus. Mun. Funchal, 12, 5-15.

Frey R., 1945. Tiergeographische Studieb uber die Dipterenfauna der Azorean. I. Verzeichnis der bisher von den Azoren bekannten Dipteren. Societas Scientiarum Fennica. Commentationes Biologicae, VIII, 1-114.

Gendron J.M. and Laville H., 1995. Biodiversity and sampling frequency of the pupal exuviae of Chironomidae (Diptera) in a 4th order river. Archiv für Hydrobiologie, 135, 243-257.

Giller P.S. and Malmqvist B., 1998. The Biology of Streams and Rivers, Oxford University Press, Oxford, 296.

Gonçalves V., Raposeiro P. and Costa A.C., 2008. Benthic diatoms and macroinvertebrates in the assessment of the ecological status of Azorean streams. Limnetica, 27, 317-328.

Harding J.S., Benfield E.F., Bolstad P.V., Helfman G.S. and Jones E.B.D., 1998. Stream biodiversity: the ghost of land use past. Proceedings of the Natural Academy of Science U.S.A., 95 .

Hardwick R.A., Cooper P.D., Cranston P.S., Humphrey C.L. and Dostine P.L., 1995. Spatial and temporal distribution patterns of drifting pupal exuviae of Chironomidae (Diptera) in streams of tropical northern Australia. Freshwat. Biol., 34, 569-578.

Heino J., 2000. Lentic macroinvertebrate assemblage structure along gradients in spatial heterogeneity, habitat size and water chemistry. Hydrobiologia, 418, 229-242.

Heino J., 2005. Functional biodiversity of macroinvertebrate assemblages along major ecological gradients of boreal headwater streams. Freshwat. Biol., 50, 1578-1587.

Heino J. and Paasivirta L., 2008. Unravelling the determinants of stream midge biodiversity in a boreal drainage basin. Freshwat. Biol., 53, 884-896.

Hering D., Johnson R.K., Kramm S., Schmutz S., Szoszkiewicz K. and Verdonschot P.F.M., 2006. Assessment of European streams with diatoms, macrophytes, macroinvertebrates and fish: a comparative metric-based analysis of organism response to stress. Freshwat. Biol., 51, 1757-1785.

Hilsenhoff W.L., 1988. Rapid Field Assessment of Organic Pollution with a Family-Level Biotic Index. J. N. Am. Benthol. Soc., 7, 65-68.

Hughes S.J., 2003. A study of the freshwater macroinvertebrate fauna of Madeira and their application in a regional ecological monitoring system. $\mathrm{PhD}$ thesis, University of London, UK, 328.

Hughes S.J., 2005. Application of the Water Framework Directive to Macaronesian freshwater systems. Biology and Environment: Proceedings of the Royal Irish Academy, 105B, 185-193.

Hughes S.J., 2006. Temporal and spatial distribution patterns of larval trichoptera in Madeiran streams. Hydrobiologia, 553, $27-41$.

Hughes S.J., 2008. Chironomidae (Diptera). In: Borges P.a.V., Abreu C., Aguiar A.M.F., Carvalho P., Jardim R., Melo I., Oliveira P., Sérgio C., Serrano A.R.M. and Vieira P. (eds.), list of the terrestrial fungi, flora and fauna of Madeira and Selvagens archipelagos, Direcção Regional do Ambiente da 
Madeira and Universidade dos Açores, Funchal and Angra do Heroísmo, 330-331.

Hughes S.J. and Malmqvist B., 2005. Atlantic Island freshwater ecosystems: challenges and considerations following the EU Water Framework Directive. Hydrobiologia, 544, 289-297.

Hughes S.J., Santos J.M., Ferreira M.T., Caraça R. and Mendes A.M., 2009. Ecological assessment of an intermittent Mediterranean river using community structure and function: evaluating the role of different organism groups. Freshwat. Biol., 54, 2383-2400.

Inoue E., Kawai K. and Imabayashi H., 2005. Species composition and assemblage structure of chironomid larvae (Diptera: Chironomidae) attaching to the artificial substrates in a Japanese temperate basin, in relation to the longitudinal gradient. Hydrobiologia, 543, 119-133.

Kohler S.L., 1992. Competition and the structure of a benthic stream community. Ecol. Monogr., 62, 165-188.

Langton P.G., 1991. A key to Pupal Exuviae of West Palaeartic Chironomidae, Privately published, Huntington, UK, 386.

Langton P.H. and Visser H., 2003. Chironomidae exuviae - A key to pupal exuviae of the West Palaearctic Region. Expert Center for Taxonomic Information, Amsterdam.

Legendre P. and Anderson M.J., 1999. Distance-based redundancy analysis: testing multispecies responses in multifactorial ecological experiments. Ecol. Monogr., 69, 1-24.

Lindegaard C. and Brodersen K., 1995. Distribution of Chironomidae (Diptera) in the River continuum. In: Peter C. (ed.), Chironomids. From Genes to Ecosystems, CSIRO, Australia, 257-271.

Louvat P. and Allegre C.J., 1998. Riverine erosion rates on Sao Miguel volcanic island, Azores archipelago. Chem. Geol., 148, 177-200.

Maasri A., Fayolle S., Gandouin E., Garnier R. and Franquet E., 2008. Epilithic chironomid larvae and water enrichment: is larval distribution explained by epilithon quantity or quality? J. N. Am. Benthol. Soc., 27, 38-51.

Macneil C., Dick J.T.A. and Elwood R.W., 1999. The dynamics of predation on Gammarus spp. (Crustacea: Amphipoda). Biol. Rev. Cam. Philos. Soc., 74, 375-395.

Magalhaes B., Batalha D.C. and Collares-Pereira M.J., 2002. Gradients in stream fish assemblages across a Mediterranean landscape: contributions of environmental factors and spatial structure. Freshwat. Biol., 46, 1015-1031.

Magurran A.E., 2004. Measuring Biological Diversity, Blackwell Publishing, Oxford, UK, 256.

Malmqvist B., 2002. Aquatic invertebrates in riverine landscapes. Freshwat. Biol., 47, 679-694.

Massaferro J. and Brooks S.J., 2002. Response of chironomids to Late Quaternary environmental change in the Taitao Peninsula, southern Chile. J. Quatern. Sci., 17, 101-111.

Mcardle B.H. and Anderson M.J., 2001. Fitting multivariate models to community data: A comment on distance-based redundancy analysis. Ecology, 82, 290-297.

Mellado A., 2005. The ecology of stream macroinvertebrate assemblages from the Segura River Basin (SE Spain). Environmental factors, spatio-temporal variability, indicator taxa, diversity trends, biological-ecological traits and applications for bioassessment. PhD Thesis, University of Murcia, Spain.

Milner A.M. and Petts G.E., 1994. Glacial rivers: physical habitat and ecology. Freshwat. Biol., 32, 295-307.
Moore A.A. and Palmer M.A., 2005. Invertebrate biodiversity in agricultural and urban headwater streams: implications for conservation and management. Ecol. Appl., 15, 1169-1117.

Munné A. and Prat N., 2009. Use of macroinvertebrate-based multimetric indices for water quality evaluation in Spanish Mediterranean rivers: an intercalibration approach with the IBMWP index. Hydrobiologia, 628, 203-225.

Murray D.A., Hughes S.J., Furse M.T. and Murray W.A., 2004. New records of Chironomidae (Diptera: Insecta) from the Azores, Macaronesia. Ann. Limnol. - Int. J. Limnol., 40, 33-42.

Mykrä H., Heino J. and Muotka T., 2007. Scale-related patterns in the spatial and environmental components of stream macroinvertebrate assemblage variation. Global Ecol. Biogeogr., 16, 149-159.

Oromí P. and Báez M., 2001. División Arthropoda. In: Izquierdo I., Martín J.L., Zurita N. and Arechavaleta M. (eds.), Lista de especies silvestres de Canaries (hongos, plantas y animales terrestres), Consejería de Política Territorial y Medio Ambiente Gobierno das Canarias, 149-284.

Osborne S., Hurrell S., Simkiss K. and Leidi A., 2000. Factors influencing the distribution and feeding of the larvae of Chironomus riparius. Entomol. Exp. Appl., 94, 67-73.

Peeters E.T.H.M., Gylstra R. and Vos J.H., 2004. Benthic macroinvertebrate community structure in relation to food and environmental variables. Hydrobiologia, 519, 103-115.

Pinder L.C.V., 1986. Biology of Freshwater Chironomidae. Annu. Rev. Entomol., 31, 1-23.

Punti T., Rieradevall M. and Prat N., 2007. Chironomidae assemblages in reference condition Mediterranean streams: environmental factors, seasonal variability and ecotypes. Fundam. Appl. Limnol., 170, 149-165.

Punti T., Rieradevall M. and Prat N., 2009. Environmental factors, spatial variation, and specific requirements of Chironomidae in Mediterranean reference streams. $J . N$. Am. Benthol. Soc., 28, 247-265.

Quaternaire-Portugal, 2008. O Plano Regional de Ordenamento do Território dos Açores, Secretaria Regional do Ambiente e Mar, Ponta Delgada.

Raposeiro P., 2010. Chironomidae. In: Borges P.a.V., Costa A., Cunha R., Gabriel R., Gonçalves V., Frias Martins A.M., Melo I., Parente M., Raposeiro P., Rodrigues P., Santos R.S., Silva L. and Vieira V. (eds.), A list of the terrestrial and marine biota from the Azores, Princípia, Cascais, 234-235.

Raposeiro P.M. and Costa A.C., 2009. Benthic macroinvertebrate based indices for assessing the ecological status of freshwaters on oceanic islands. Arquipelago - Life Mar. Sci., $26,15-24$.

Raposeiro P.M., Cruz A.M. and Hughes S.J., in press. Azorean freshwater invertebrates: Status, threats and biogeographic notes. Limnetica.

Raposeiro P.M., Hughes S.J. and Costa A.C., 2009. Chironomidae (Diptera: Insecta) in oceanic islands: New records for the Azores and biogeographic notes. Ann. Limnol. - Int. J. Limnol., 45, 59-67.

Raunio J., Ihaksi T., Haapala A. and Muotka T., 2007a. Withinand among-lake variation in benthic macroinvertebrate communities: comparison of profundal grab sampling and the chironomid pupal exuvial technique. J. N. Am. Benthol. Soc., 26, 708-718.

Raunio J., Paavola R. and Muotka T., 2007b. Effects of emergence phenology, taxa tolerances and taxonomic 
resolution on the use of the Chironomid Pupal Exuvial Technique in river biomonitoring. Freshwat. Biol., 52, 165176.

Rosenberg D.M. and Resh V.H., 1993. Introduction to freshwater biomonitoring and benthic macroinvertebrates. In: Rosenberg D.M. (ed.), Freshwater Biomonitoring and Benthic Macroinvertebrates., Kluwer, London, 1-9.

Ruse L. and Davison M., 2000. Long-term data assessment of chironomid taxa structure and function in the river Thames. Regul. Rivers: Res. Manage., 16, 113-126.

Ruse L.P., 1993. Chironomid distribution in the River Pang in relation to environmental variables, University of Bristol, $\mathrm{PhD}$ Thesis.

Ruse L.P., 2000. A simple key to water quality based on chironomid pupal exuviae. In: Hoffrichter O. (ed.), Late 20th Century Research on Chironomidae: an Anthology from the 13th Internacional Symposium on Chironomidae., Shaker Verlag, Germany, 405-413.

Ruse L.P. and Wilson R.S., 1995. Long-term assessment of water and sediment quality of the River Thames using Chironomid pupal skins. In: Peter C. (ed.), Chironomids. From Genes to Ecosystems, CSIRO, Australia, 113-124.

Saether O.A. and Spies M., 2009. Fauna Europaea: Chironomidae. In: De Jong H. (ed.), Fauna Europaea: Diptera: Nematocera, Fauna Europaea version 2.1, http:// www.faunaeur.org.

Silva L. and Smith C.W., 2004. A Characterization of the Nonindigenous Flora of the Azores Archipelago. Biol. Invasions, 6, 193-204.

Soininen J., Paavola R. and Muotka T., 2004. Benthic diatom communities in boreal streams: community structure in relation to environmental and spatial gradients. Ecography, 27.

Stora R., 1945. Chironomidae. In: Frey R. (ed.), Tiergeographische Studien über die Dipterenfauna der Azoren. I Verzeichnes der bisher von der Azoren bekannten Dipteren, Societas Scientarum Fennica. Commentations Biologicae, 1-114.

Tokeshi M., Cranston P.S. and Pinder L.C.V., 1995. 10 Life cycles and population dynamics. In: Armitage P.D. (ed.), The Chironomidae: Biology and ecology of non-biting midges., Chapman \& Hall, London, 225-268.

Tolonen K.T., Hamalaainen H., Holopainen I.J. and Karjalainen J., 2001. Influences of habitat type and environmental variables on littoral macroinvertebrate communities in a large lake system. Archiv fur Hydrobiologie, 152, 39-67.
Townsend C.R. and Hildrew A.G., 1994. Species traits in relation to a habitat templet for rivers systems. Freshwat. Biol., 31, 265-275.

Townsend C.R., Hildrew A.G. and Schofield K., 1987. Persistence of stream invertebrate communities in relation to environmental variability. J. Anim. Ecol., 56, 597-613.

Vallenduuk H.J. and Moller Pillot H.K.M., 2007. Chironomidae Larvae: General ecology and Tanypodinae, KNNV, Budel, 144.

Vannote R.L., Minshall G.W., Cummins K.W., Sedell J.R. and Cushing C.E., 1980. The River Continuum Concept. Can. J. Fish. Aquat. Sci., 37, 130-137.

Walter H.S., 2004. The mismeasure of islands: implications for biogeographical theory and the conservation of nature. $J$. Biogeogr., 31, 177-197.

Weijters M.J., Janse J.H., Alkemade R. and Verhoeven J.T.A., 2009. Quantifying the effect of catchment land use and water nutrient concentrations on freshwater river and stream biodiversity. Aquat. Conserv.: Mar. Freshwat. Ecosyst., 19, 104-112.

White J. and Irvine K., 2003. The use of littoral mesohabitats and their macroinvertebrate assemblages in the ecological assessment of lakes. Aquat. Conserv.: Mar. Freshwat. Ecosyst., 13, 331-351.

Whittaker R.J. and Fernandez-Palacios J.M., 2007. Island Biogeography. Ecology, Evolution, and Conservation, Oxford University Press, Oxford, 401.

Wilson R., 1992. Monitoring organic enrichment of rivers using chironomid pupal exuvial assemblages. Aquat. Ecol., 26, 521-525.

Wilson R.S. and Bright P.L., 1973. The use of chironomid pupal exuviae for characterizing streams. Freshwat. Biol., 3, 283302.

Wilson R.S. and Ruse L.P., 2005. A guide to the identification of genera of chironomid pupal exuviae occurring in Britain and Ireland (including common genera from northern Europe) and their use in monitoring lotic and lentic freshwaters, Freshwater Biological Association, Cumbria, UK, 176.

Winterbourn M.J., 1997. New Zealand mountain stream communities: Stable yet disturbed? In: Streit B., Stadler T. and Lively C.M. (eds.), Evolutionary Ecology of Freshwater Animals, Birkhauser Verlag, Basel, Switzerland, 31-54.

Wrubleski D.A. and Rosenberg D.M., 1990. The Chironomidae (Diptera) of Bone Pile Pond, Delta Marsh, Manitoba, Canada. Wetlands, 10, 243-275. 